\title{
The first record of Physalis angulata L. (Solanaceae) for the flora of Libya
}

\author{
Mohammed H. Mahklouf
}

Department of Botany, Faculty of Sciences, Tripoli University, Tripoli-Libya, e-mail: mahklouf64@yahoo.com; ORCID: https://orcid. org/0000-0001-8402-797X

\begin{abstract}
Physalis angulata has been discovered and recorded for the first time in the flora of Libya. This species was collected from the Bilash'har region belonging to the city of Tajura, about $20 \mathrm{~km}$ east of Tripoli. $P$. angulata is easily identified by its small yellow flowers without central dark spots in the center, and by pedulus globose berry enclosed within an inflated bladdery fruiting calyx. Detailed descriptions, photographs, habitat and ecology are provided for easy identification, and to facilitate further identification of this species and to warrant its future detection.
\end{abstract}

Key words: Physalis angulata, Solanaceae, Wild tomato, Gooseberry, Ribes uva-crispa

\section{Introduction}

The name Physalis is from the Greek, meaning 'bladder', and refers to the inflated calyx. The genus is a member of the Nightshade family, Solanaceae (Mahalakshmi \& Nidavani1 2014). Physalis species are annuals or perennials, erect or decumbent, sometimes rhizomatous, glabrous or pubescent, and with variously toothed or lobed leaves (Mahalakshmi \& Nidavani1 2014). The genus Physalis is consisting of about 90100 species (Mahklouf 2016; Sultana et al. 2008). It is thought that it originated in Mexico and presently, it is mainly distributed in tropical, south, and temperate America, although some species have a world-wide distribution (Kindscher et al. 2012; Rengifo-Salgado \& Vargas-Arana 2013).

Most species of Physalis are native to America, except $P$. alkekengi that is native to the Old World (Hunziker 2001; Toledo \& Barboza 2005). Physalis is a clearly defined genus, in the subfamily Solanoideae, tribe Physaleae (Toledo 2013; Samuels 2015), and has a distinctive fruit, a globose two-carpelate berry, small or large (4-7/10-20 $\mathrm{mm}$ in diameter) with either juicy or rather dry pericarp, enclosed in the inflated bladdery calyx (Martínez 1998; Hunziker 2001; Arenas \& Kamienkowski 2013).

The centre of diversity of Physalis is Mexico, with most of species endemic to this area; two other centres of the species diversity and endemism are United States and Central America (Martínez 1998). A few species are cultivated in the temperate and tropical Old World and in Australia, while others (mainly P. peruviana and $P$. angulata) are ruderal plants or weeds (National research Council 1989; Hunziker 2001). These plants were introduced into warm areas of the world in post-Columbian times, as a result of the voyages of exploration, discovery and commercial exploitation that began in the 16th century (Hedrick 1919; Arenas \& Kamienkowski 2013).

The genus Physalis contains many species grown for their ornamental or edible fruits that are eaten raw or cooked. The most commonly cultivated species in North America is the tomatillo (P. philadelphica), which is often cultivated for food and used in salsa verde. Many other species, such as the Cape gooseberry (P. peruviana) and the husk tomato or muyaca in South America (P. pubescens), have been cultivated and eaten for their acidulous fruits (Von Mueller 1895). The Chinese lantern plant ( $P$. alkenkengi) is an ornamental species that is cultivated for its brightly colored orangered husk (Kelly et al. 2012; Mahalakshmi \& Nidavani1 2014)

P. angulata is popularly known as Camapu, Cutleaf groundcherry, Wild tomato, Winter cherry, Cow pops, Chinese lantern, Mullaca, Koropo (in Western Africa) and Wild gooseberry, and has herbal characteristics 


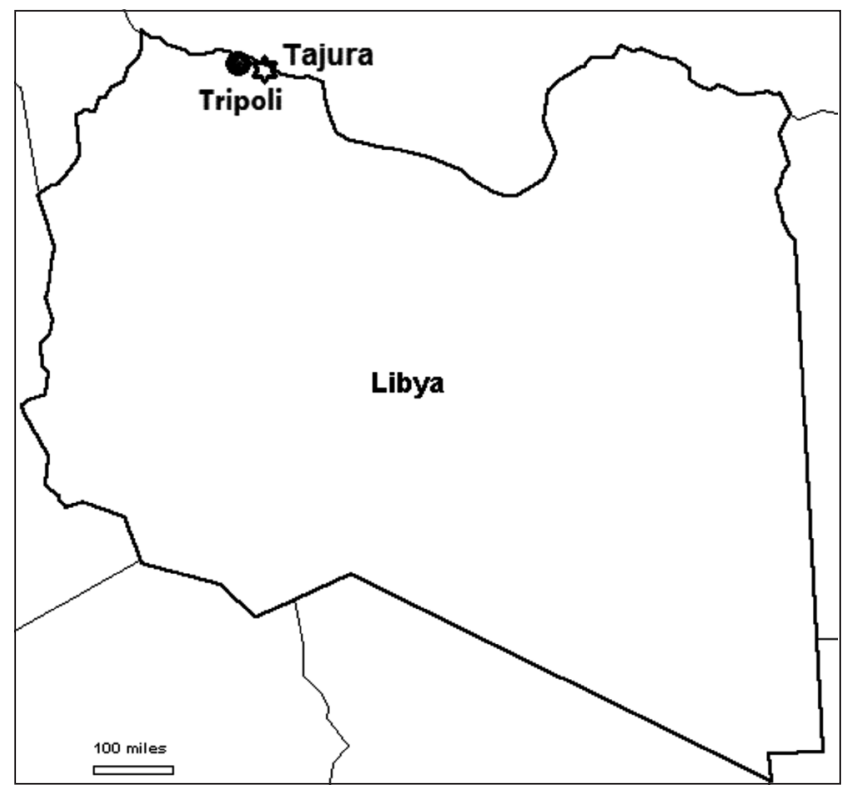

Fig. 1. A map of Libya showing the city of Tajura (Tajoura)

and perennial habit (Mahalakshmi \& Nidavani1 2014).

\section{Material and methods}

Plant specimens were reported from Bilash'har area belonging to the city of Tajura about $20 \mathrm{~km}$ east of Tripoli, $\left(32^{\circ} 52^{\prime} 33.97^{\prime \prime} \mathrm{N}\right.$, and 13०19'04.65” E) for two consecutive seasons 2017-2018, (Figs. 1-2). Plant specimens were collected by the author several times at the flowering and fruiting stages, brought to the herbarium and subjected to ordinary herbarium techniques (pressing, drying, mounting, labeling). Then, they were examined carefully and characterized with detailed description. This procedure can facilitate the detection of new populations, supposing that $P$. angulata will continue to spread in the Libya territory.

The identification authentication of this species was done by the author, based on the data from the following literature sources: Mahklouf(2016), Sultana et al. (2008) and Gonen et al. (2000). The collected specimens were given a voucher number (76.62.8.2) and then deposited at the National Herbarium of the Department of Botany (ULT), Faculty of Sciences, Tripoli University, Libya.

Photogaphs were taken by the author and Mr Salem Saa'rana.

\section{Results and discussion}

The description was provided by the author based on the examined specimens.

Physalis angulata L. Sp. Pl. 1: 183. 1753.

Synonym: Physalis pendula Rydb. Physalis angulata L. var. angulata; Physalis ciliata Sieber; Physalis minima L.; Physalis minima L. var. indica (Lam.) C. B. Clarke.; Physalis indica Lam.; Physalis parviflora $\mathrm{R}$. Br.

English names: Gooseberry, Hogweed, Balloon Cherry.

D e s cription: Annual herb up to $100 \mathrm{~cm}$ tall, with erect to procumbent stem, glabrous or with a few short appressed hairs; stems quadrangular, hollow. Leaves

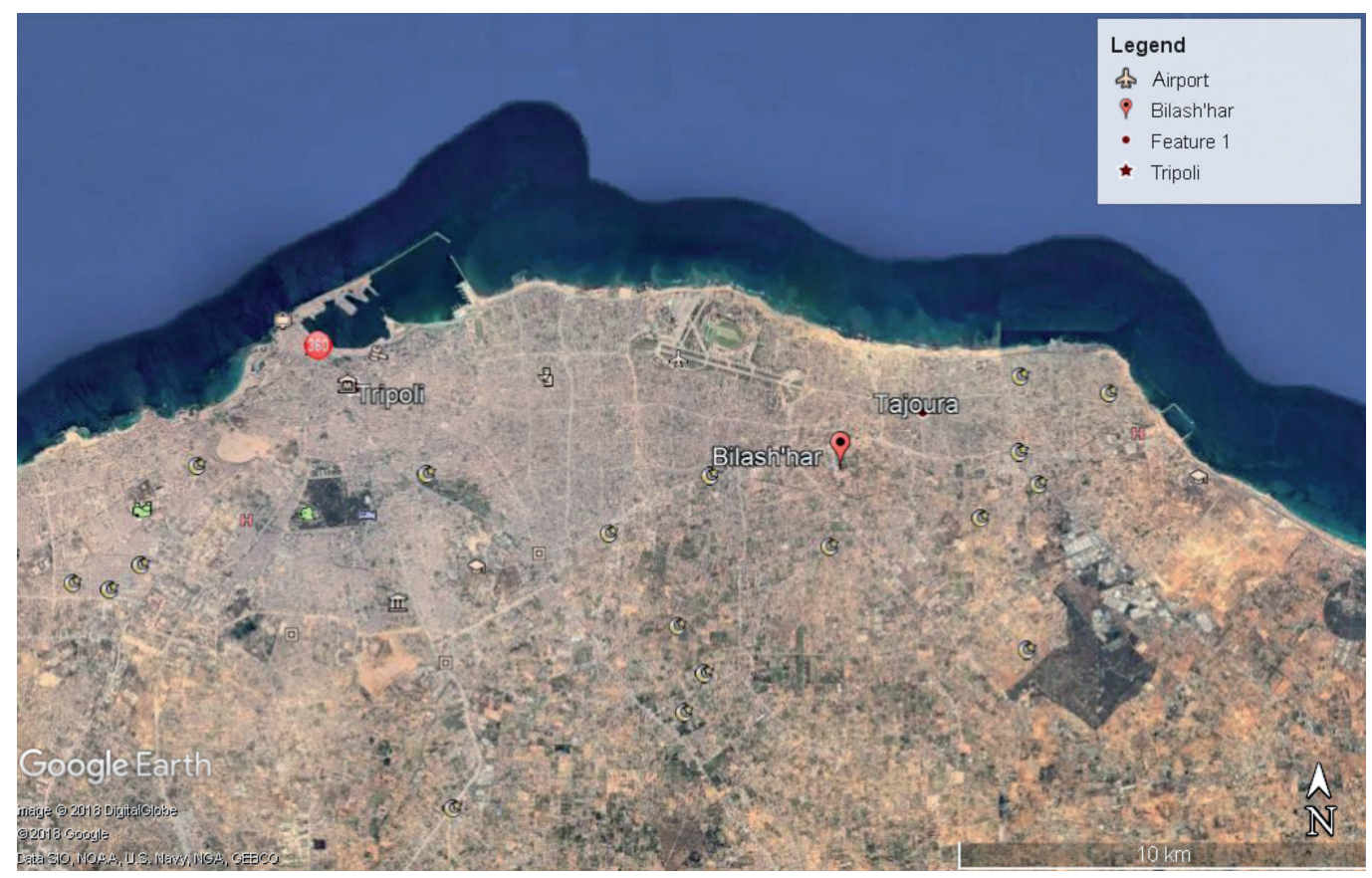

Fig. 2. A map of north-west Libya showing the site of Physalis angulata collection (Bilash'har) (source: Google earth) 

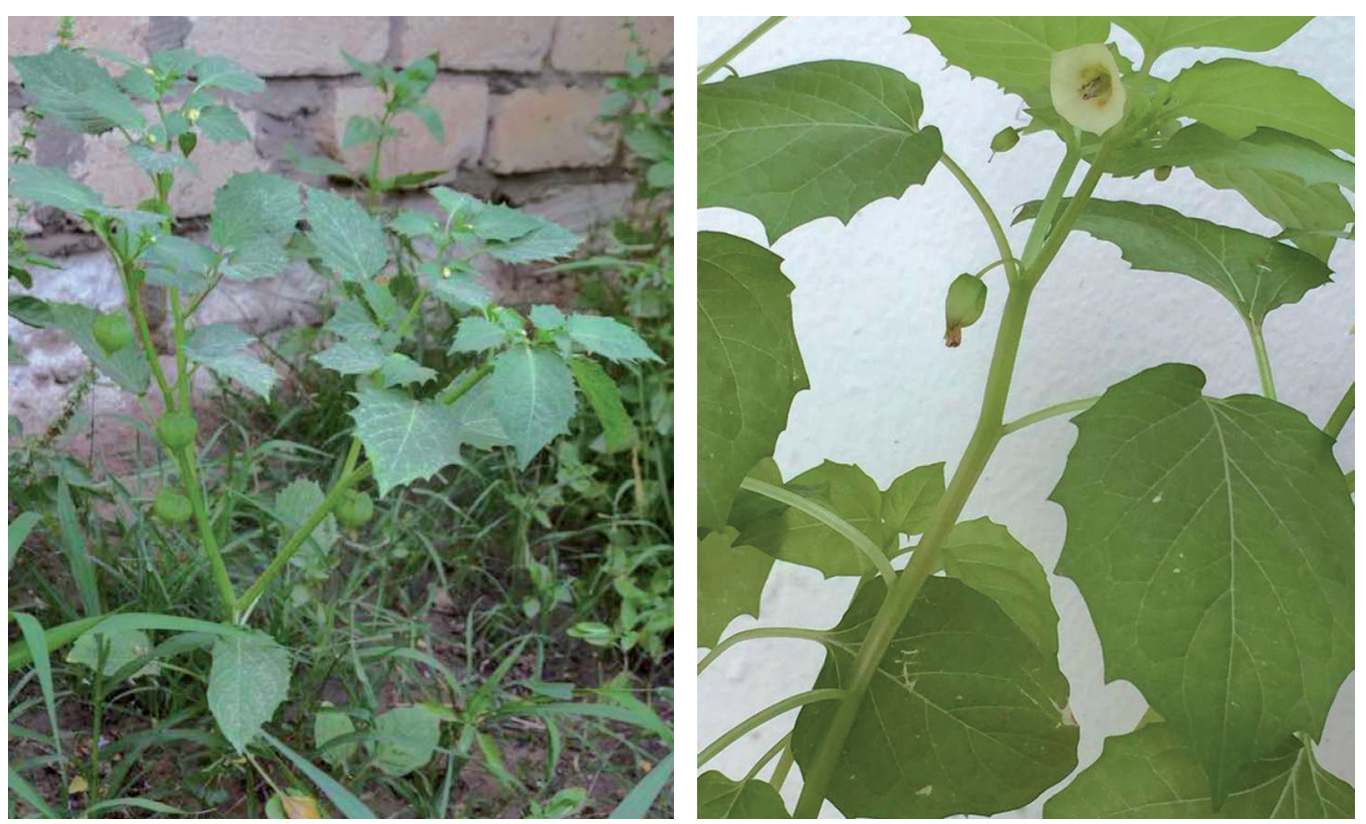

Fig. 3 and 4. Physalis angulata habit

alternate, simple; exstipulate; petiole 2-11 cm long; blade ovate to broadly ovate, $4-15 \mathrm{~cm} \times 3-10 \mathrm{~cm}$, margin irregularly toothed. Flowers axillary, solitary, spreading or nodding, bisexual, regular, 5-merous; pedicel 6-12 $\mathrm{mm}$ long, elongated in fruit up to $22 \mathrm{~mm}$; calyx campanulate, 5-lobed, 3-5 mm long, lobes acute, as long as tube, angled or ribbed, fruiting calyx $2-4 \mathrm{~cm}$ long; corolla campanulate, 6-13 mm long, pale yellow with faint 5 spots inside; stamens inserted near the base of the corolla tube, filaments $2-5 \mathrm{~mm}$ long, anthers bluepurple; ovary superior, 2-celled, style filiform, stigma capitata. Fruit a globose berry $10-16 \mathrm{~mm}$ in diameter, pendulous, yellow, viscid, many-seeded, enclosed in the persistent, inflated bladdery calyx, which is 10 ribbed and 5-angled. Seeds many, reniform, 1.5-2.0 $\mathrm{mm} \times 1.0$ $1.5 \mathrm{~mm}$, pale brown (Figs. 3-6).

Flowering and fruiting: Almost throughout the year. (From. Sultana et al. 2008).

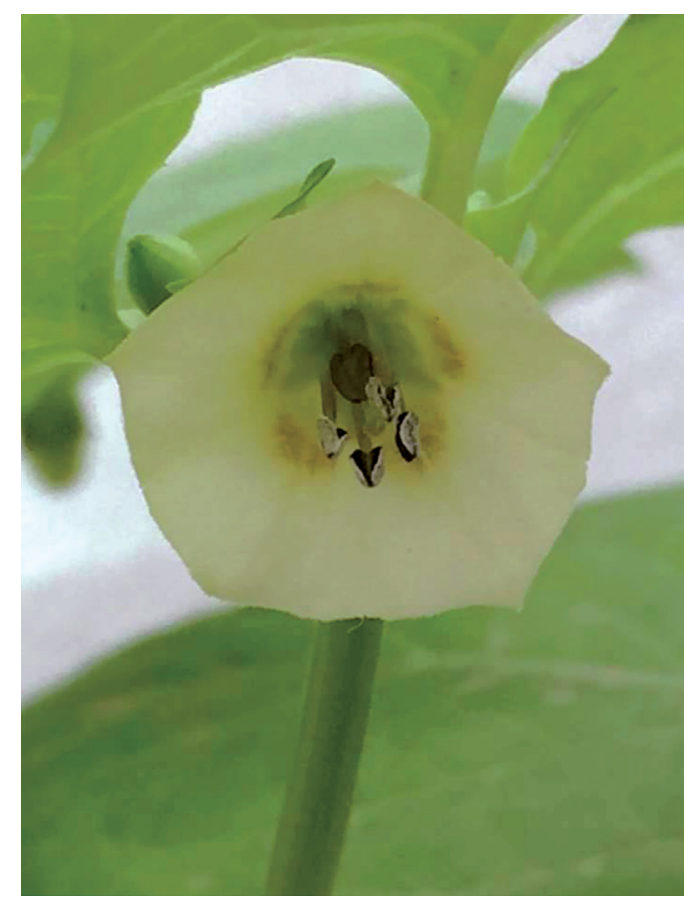

Fig. 5. Close-up of Physalis angulata flower

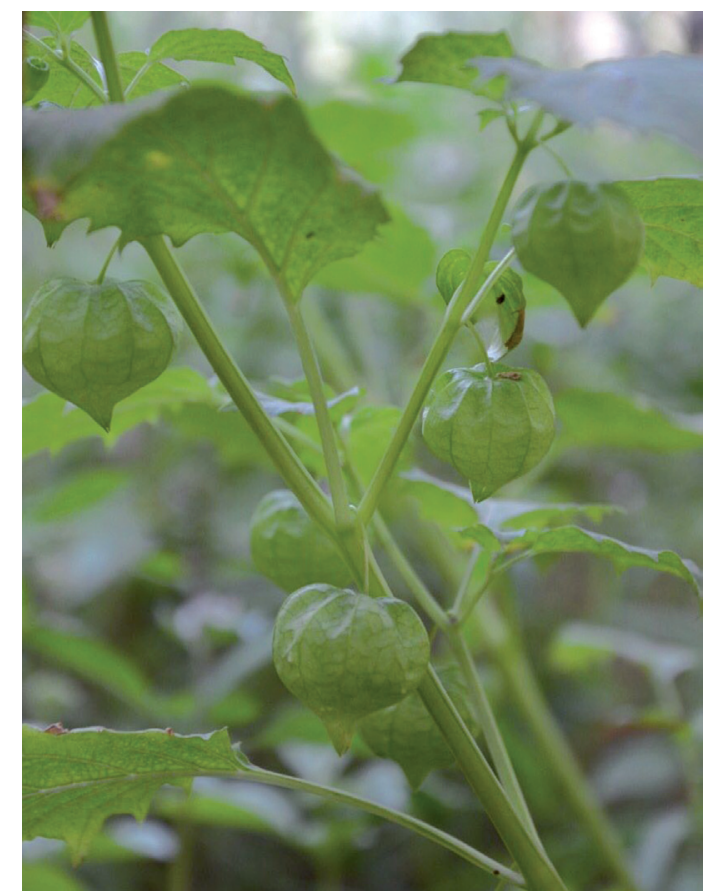

Fig. 6. Physalis angulata fruits 


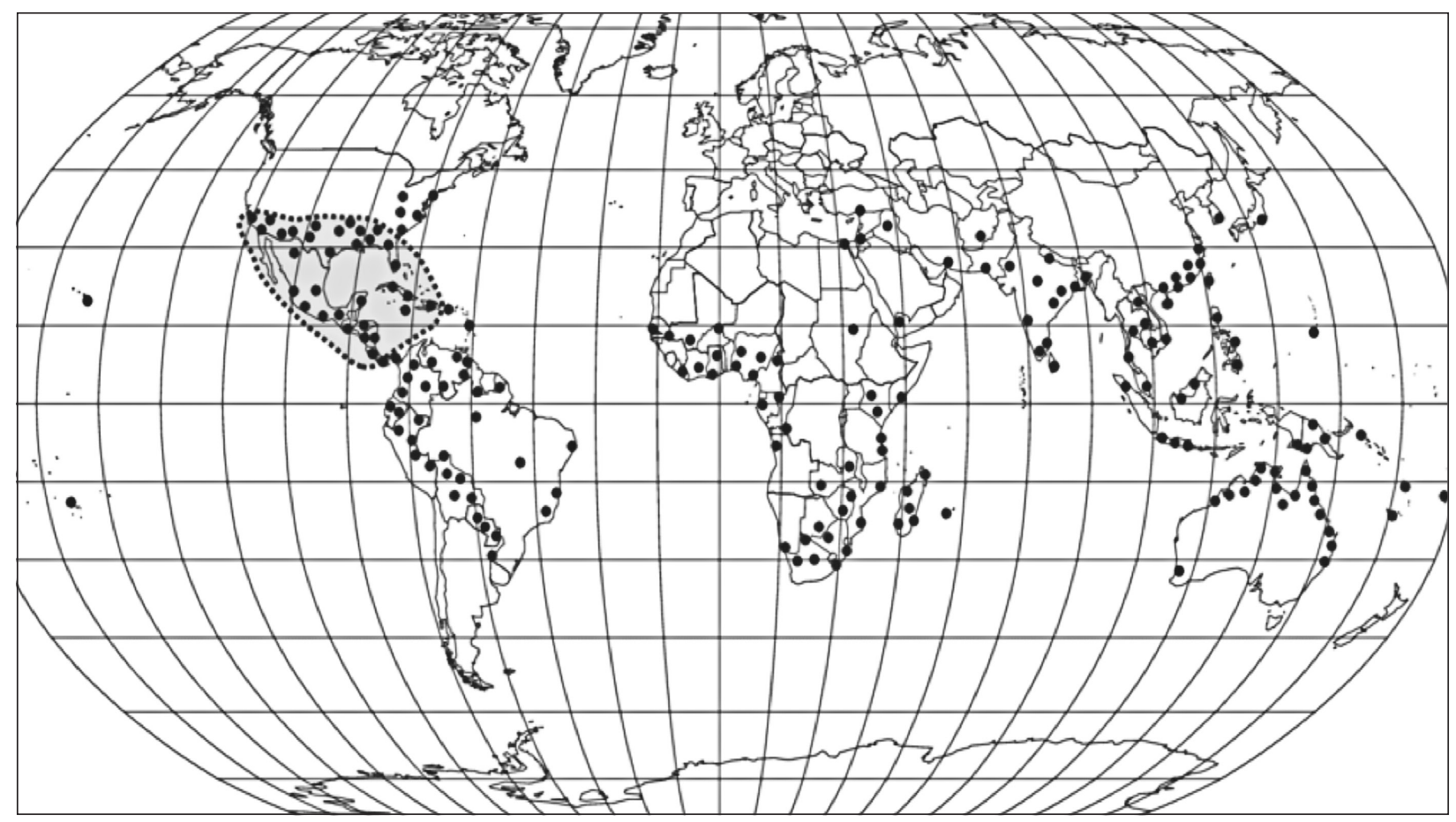

Fig. 7. Distribution of Physalis angulata

Explanation: the dots indicate the current distribution of $P$. angulata (on the basis of Flora treatments and herbarium specimen records); the shaded area represents the approximate area of ancient distribution [according to Martínez (1999)]

Chromosome number: 2 n=24, 48 (Fedorov 1969; Sultana et al. 2008). Tetraploid ( $2 n=48)$ (Raju et al. 2007).

Physalis angulata is reported for the first time from the Bilash'har area, belonging to the city of Tajura, about $20 \mathrm{~km}$ east of Tripoli (32 $52^{\prime} 33.97^{\prime \prime} \mathrm{N}$, and $13^{\circ} 19^{\prime}$ $04.65^{\prime \prime}$ E). The identification of this species was done using the data from the following literature sources: Mahklouf 2016, Sultana et al. 2008, and Gonen et al. 2000 . In addition, it is easily recognized by its yellow flowers without dark spots or with faint spots in the center, and pendulous globose green berry enclosed within the inflated balddery fruiting calyx.

$P$. angulata was previously identified as $P$. lanceifolia (Jepson 1951). According to Gleason (1958), P. pendula and $P$. angulata were identified as two different species. Three varieties of $P$. angulata were recorded by Correl (1970): var. angulata, var. lanceifolia and var. pendula. $P$. pendula was recorded as the var. angulata in the eastern and southeastern USA in 1986. Finally, $P$. lanceifolia and $P$. pendula were recorded as synonyms of $P$. angulata in 1994 (Mahklouf 2016; Gonen et al. 2000).

P. angulata is an exotic species native to tropical America and currently it has a typical tropical and pantropical distribution as shown in Fig. 6 (Martínez 1999; Bean 2007). It should be considered a potential invader in the Mediterranean ecosystems, especially, in the East Mediterranean, where it was recorded in
Egypt by Tackholm (1974), reported from Turkey by Gonen et al. (2000), and from Iraq by Al-Ellagi (2012). Then, it was recorded from Syria by Mahklouf (2016) (Fig. 7), thus, this record constitutes a new point of spread of this species in the Mediterranean region, especially, it is the first record in north Africa and the West Mediterranian.

In the flora of Libya, only one species, P. peruviana, was recorded to be cultivated by Keith (1965), without locality or specimen in the herbarium (Siddiqi 1978), thus our present report is the first decumented record of the genus Physalis represented by the species $P$. angulata, here is a key provided to distinguish this species from $P$. peruviana.

- Plant annual, glabrous, leaves irregularly dentateserrate, corolla $0.6-1.3 \mathrm{~mm}$ a cross. Without dark purple spots or withfaint spots inside, berry green

P. angulata

- Plant perennial, densely tomentose, leaves entire or undulate, corolla $1.5-2.5 \mathrm{~cm}$ a cross, with dark purple spots inside, berry yellow

P. peruviana

The species $P$. angulata is widespread as a weed and it is also cultivated for various purposes, including medicinal, food, forage, ornamental and other usages (Mahalakshmi \& Nidavani 2014).

Acknowledgements. I am grateful to Mr Salem Shaarana and his daughter Rowaeda for their kind Help in collecting plant specimens and taking field photographs of the studied species. 


\section{References}

Al-Ellagi S. 2012, New record Physalis angulata (Solanaceae) to the Flora of Iraq. J Sci Univ Al-Nahreen.15(4): 31- 42.

Arenas P. \& Kamienkowski N. 2013. Ethnobotany of the genus Physalis L. (Solanaceae) in the South American Gran Chaco. Candollea 68(2): 251-266.

BEAN A. R. 2007. A new system for determining which plant species are indigenous in Australia. Aust Syst Bot 20: 1-43.

Correl D. S. \& Johnston M. C. 1970. Manual of the Vascular Plants of Texas, pp. 1387-1391. Texas Research Foundation, Renner, Texas.

Fedorov A. A. 1969. Chromosome Numbers of Flowering Plants. 926 pp. Academy of Science of USSR, Moscow.

Gleason H. A. 1958. The New Britton and Brown Illustrated Flora of the Northeastern United States and Adjacent Canada. Vol. 3, Second edition, pp. 193-199.

Gonen O., Yildirim A. \& Uygur F. N. 2000. New Record for the Flora of Turkey Physalis angulata L. (Solanaceae). Turk J Bot. 24: 299-301.

Hedrick U. P. 1919. Sturtevant's notes on edible plants. State of New York Department of Agriculture 2, II. J. b. Lyon Company, State Printers. Albany.

Hunziker A. T. 2001. Genera Solanacearum. The genera of Solana ceae illustrated, arranged according to a new system. Gantner Verlag. Ruggell.

JEPSON W. L. 1951. A manual of the Flowering Plants of California. California Press. Berkeley and Los Angeles. p. 893- 894.

Keith H. G. 1965. Libyan Flora. Ministry of Agriculture and Agrarian Rerorm. Libyan Arab Republic.

Kelly K., Quinn L., Steve C., Kirsten B., Hillary L., Mark C. \& Barbara N. T. 2012. The Ethnobotany and Ethnopharmacology of Wild Tomatillos, Physalis longifolia Nutt., and Related Physalis Species: A Review. Economic Botany 20(10): 1-13.

Kindscher K., Long Q., Corbett S., Bosnak K., Loring H., Cohen M. \& Timmermann B. N. 2012. The Ethnobotany and Ethnopharmacology of Wild Tomatillos, Physalis longifolia Nutt., and Related Physalis Species: A Review1. Economic Botany, pp. 1-13.

Mahalakshmi A. M \& Nidavani R. B. 2014. Physalis Angulata L.: An Ethanopharmacological Review.
Indo American Journal Of Pharmaceutical Research. 4(3): 1479-1486.

Mahklouf M. H. 2016. A New Record Physalis angulata L. (Solanaceae) for the Flora of Syria. American Journal of Life Science Researches. 2(1): 9-11.

Martínez M. 1998. Revision of Physalis section Epeteiorhiza (Solanaceae). Anales Inst. Biol. Univ. Nac. Auton. Mexico, Bot. 69: 71-117.

Martínez M. 1999. Infrageneric taxonomy of Physalis. In: M. Nee, D. E. Symon, R. N. Lester \& J. P. Jessop (eds.). Solanaceae IV, pp. 275-283. Kew, Royal Botanic Gardens.

National Research Council. 1989. Lost crops of the Incas: Little-Known plants of the Andes with promise for worldwide cultivation, pp. 240-251. National Academic Press. Washington.

Rengifo-Salgado E. \& Vargas-Arana G. 2013. Physalis angulata L. (Bolsa Mullaca): A Review of its Traditional Uses, Chemistry and Pharmacology. Boletín Latinoamericano y del Caribe de Plantas Medicinales y Aromáticas 12(5): 431-445.

SAmuels J. 2015. Biodiversity of Food Species of the Solanaceae Family: A Preliminary Taxonomic Inventory of Subfamily Solanoideae. Resources 4: 277-322.

SIDDIQI M. A. 1978. Flora of Libya (Solanaceae). Al-Faateh University, Faculty od Sciences. Vol 62: 29-30.

Sultana N., Hassan M. A., Begum M. \& Sultana M. 2008. Physalis angulata L. (Solanaceae) - A New Angiospermic Record For Bangladesh. Bangladesh J Bot 37(2): 195-198.

Tаскноцм V. 1974. Students flora of Egypt. 2nd ed. Beirut: Cooperative Printing Co.

Toledo J. M. 2013. Physalis victoriana (Solanaceae) a new species from Northern Argentina. Phytotaxa 124(1): 60-64.

Toledo J. M. \& Barboza G. E. 2005. Novedades en Physalis (Solanaceae). Kurtziana 31: 69-85.

Raju S. V., Reddy C. S \& Rajarao K. G. 2007. The myth of "minima" and "maxima", the species of Physalis in the Indian Subcontinent. Acta Phytotaxonomica Sinica 45(2): 239-245.

Von Mueller B. F. 1895. Select Extra-Tropical Plants, Readily Eligible for Industrial, Culture or Naturalisation. Robert Drain, Government Printer, Melbourne, Australia. 